\title{
MEMBENTUK KARAKTER PEDULI LINGKUNGAN DENGAN PENDIDIKAN
}

\author{
Masruroh \\ Pendidikan IPS, UIN Syarif Hidayatullah Jakarta \\ masruroh.ips@uinjkt.ac.id
}

\begin{abstract}
There are many environmental issues that until now do not have many solutions yet in this country. The environment has always been a big issue in almost all urban areas. This is still a lots thing to do by peoples. To foster the character of environmental care which plays a major role in the welfare and sustainability of people's lives, then awareness must be built for each individual. One of them is through education. Education is a process of maturity. The lack of understanding and skills in preserving the environment makes vulnerable communities act to not pay attention to the preservation of the environment in which they live. Environmental Education must be provided by all components of society. Environmental education needs to be taught from an early age to form awareness of caring for the environment.
\end{abstract}

Keywords: Education, Environment and Awareness

\begin{abstract}
ABSTRAK
Persoalan lingkungan merupakan persoalan yang sampai saat ini belum banyak solusi di negeri ini. Lingkungan yang selalu menjadi isu besar di hampir seluruh wilayah perkotaan. Ini masih menjadi pekerjaan besar bagi semua masyarakat. Untuk menumbuhkan karakter peduli lingkungan yang berperan besar bagi kesejahteraan dan kesinambungan hidup masyarakat, maka harus dibangun kesadaran bagi setiap individu. Salah satunya melalui pendidikan. Pendidikan merupakan sarana pendewasaan diri. Rendahnya pemahaman dan keterampilan menjaga kelestarian lingkungan hidup, menjadikan masyarakat rentan bertindak untuk tidak memperhatikan kelestarian lingkungan tempat tinggal. Pendidikan Lingkungan wajib diberikan oleh seluruh komponen masyarakat. Pendidikan lingkungan perlu diajarkan dari dini agar membentuk kesadaran peduli pada lingkungan.
\end{abstract}

Kata Kunci: Pendidikan, Lingkungan dan Kesadaran

\section{PENDAHULUAN}

Laju pertumbuhan ekonomi di kota dimungkinkan menjadi daya tarik luar biasa bagi penduduk untuk hijrah ke kota (urbanisasi). Akibatnya jumlah penduduk semakin membengkak, konsumsi masyarakat perkotaan melonjak, yang pada akhirnya akan mengakibatkan sejumlah masalah lingkungan salah satunya yaitu jumlah sampah yang meningkat (Kompas, 13 Agustus 2003).

Permasalahan yang terjadi di kotakota besar adalah terbentuknya pemukiman kumuh, sanitasi dan sampah. Hal ini diakibatkan oleh pola hidup masyarakat kota yang cenderung tidak memperhatikan dampak terhadap lingkungan yang kemudian akan mengancam kesehatan masyarakat serta keberlanjutan lingkungan itu sendiri (Dalam Anita, 2014).

Indonesia sebagai negara berkembang tidak luput dengan adanya permasalahan perkotaan. Sampai saat ini kondisi kota akan menjadi masalah akibat adanya degradasi lingkungan, jika pola 
hidup masyarakat tetap apatis terhadap permasalahan lingkungan disekitarnya.

Rendahnya karakter peduli lingkungan yang dimilki oleh masyarakat. Masyarakat jika tidak bisa menjaga lingkungan maka alam yang akan memberi pelajaran terhadap manusia di dalamnya dengan berbagai macam bencana alam (kompasiana.com, Januari 2014).

Masalah utama lingkungan adalah masalah kerusakan hutan. Sebagai contoh di Kabupaten Lebong yang mempunyai hutan seluas $134.834,72$ ha yang terdiri dari $20.777,40$ ha hutan lindung dan $114.057,72$ ha berupa hutan konservasi, sebanyak 7.895,41 ha hutan lindung dan 2.970,37 ha cagar alam telah mengalami kerusakan (Anggatravis, 2010).

Masalah lingkungan yang lain yaitu sampah yang merupakan limbah akhir dari pemakaian manusia. Sampah menjadi sumber penyakit apabila tidak ditangani dengan baik dan benar. Dampak dari semua itu akan merugikan masyarakat yang tinggal dilingkungan yang dekat dengan pembuang akhir sampah. Masalah lingkungan merupakan tanggung jawab bersama yang harus ditanggung demi terciptanya lingkungan yang nyaman dan bersih. Untuk mewujudkan itu maka diperlukan sebuah wadah melalui pendidikan yang akan membentuk karakter peduli lingkungan bagi masyarakat. Salah satunya dimulai dengan memberikan pendidikan dari keluarga, pendidikan formal dan pendidikan informal (Meerwan http:// blog.umy.ac.id/directions/?p=24 permasalahan-dan-solusi-pengelolaanlingkungan-hidup/).

\section{METODE PENELITIAN}

Metode yang digunakan dalam penelitian ini yaitu kualitatif dengan pendekatan deskriptif. Sumber data dalam penelitian ini yaitu data primer dan data sekunder. Data primer pada penelitian ini yaitu data yang diperoleh langsung dari lapangan. Sedangkan data sekunder yaitu data tidak langsung yang didapat melalui orang lain atau berbentuk dokumen.

\section{PERMASALAHAN LINGKUNGAN DI INDONESIA}

\section{Kerusakan Hutan}

Kerusakan hutan juga disebabkan oleh kebakaran hutan. Kebakaran hutan ini dari tahun ke tahun bertambah luas. Pada tahun 1997 luas kebakaran hutan seluas 2.091 ha dengan 31 titik api. Pada tahun 2006 sebagai akibat kemarau yang panjang kebakaran hutan semakin luas yang mengakibatkan tebalnya asap di udara yang dapat menimbulkan berbagai masalah. Upaya untuk memulihkan hutan yang rusak adalah sebagai berikut:

1) Dalam jangka pendek adalah penegakan hukum. Hal ini dapat mencegah praktek-praktek ilegal logging dan perambahan hutan yang semakin luas.

2) Hendaknya kegiatan pembangunan memperhatikan aspek lingkungan.

3) Upaya penanaman kembali hutan yang telah rusak. Penghijauan telah dilakukan namun belum efektif memulihkan kondisi hutan.

4) Dalam jangka menengah dapat dilakukan sosialisasi dan pendidikan lingkungan pada orang dewasa terutama yang tinggal di sekitar hutan lindung dan konservasi.

5) Dalam jangka panjang pendidikan lingkungan menjadi salah satu pelajaran muatan lokal baik di SD, SMP, SLTA maupun di perguruan tinggi.

\section{Penurunan Keanekaragaman Hayati}

Akibat kerusakan hutan, pembukaan lahan, praktek pengolahan lahan yang kurang memperhatikan ekologi, pertanian monokultur dll., maka terjadi penurunan keanekaragaman 
hayati di Propinsi Bengkulu. Kegiatan monokultur dapat menyebabkan sebagian flora, fauna dan mikrobia musnah. Contohnya, kantong semar yang dahulu sangat banyak dijumpai di Bengkulu sekarang menjadi sedikit jumlah dan jenisnya. Upaya untuk mencegah punahnya flora dan fauna langka tersebut antara lain adalah:

1) Konservasi in-situ: upaya pelestarian flora dan fauna langka beserta ekosistemnya di kawasan konservasi. Luas hutan konservasi di Bengkulu adalah 426.203,23 ha.

2) Konservasi ex-situ: Raflesia alnordi dengan menggunakan kultur jaringan, tapi belum berhasil.

3) Program penangkaran satwa langka.

4) Penyuluhan tentang penangkaran satwa secara intensif.

5) Memberikan pendidikan kepada masyarakat tentang keanekaragaman hayati dan manfaatnya bagi masyarakat.

6) Peningkatan kemampuan sumber daya manusia.

7) Memasukkan keanekaragaman hayati ke dalam kurikulum SD, SMP, SMU serta perguruan tinggi.

\section{Kualitas Air}

Pengolahan air di PDAM saat ini memerlukan cukup banyak tawas yang berfungsi sebagai pengikat partikel lumpur. Air yang digunakan oleh PDAM juga terindikasi tercemar batubara. Air sumur di daerah peternakan ayam mengandung banyak Ecoli yang sangat tinggi. Praktek pemotongan liar juga masih marak dilakukan oleh masyarakat, sehingga dapat menurunkan kualitas air. Kerusakan hutan juga dapat menurunkan mutu air sebagai akibat peningkatan zat padat terlarut dan zat padat tersuspensi serta kekeruhan. Kerusakan hutan juga disinyalir sebagai salah satu sebab turunnya volume air di danau Dendam.

\section{Pengelolaan Sampah}

Menurut Kodoatie (2003: 312) sampah adalah limbah atau buangan yang bersifat padat, setengah padat yang merupakan hasil sampingan dari kegiatan perkotaan atau siklus kehidupan manusia, hewan maupun tumbuh tumbuhan.

Pengolahan sampah plastik adalah perlakuan terhadap sampah plastik yang bertujuan memperkecil atau menghilangkan masalah - masalah yang berkaitan dengan lingkungan (Sunaryo: 1995).

Menurut Daniel (2009) terdapat tiga jenis sampah, di antaranya:

1. Sampah organik: sampah yang terdiri dari bahan-bahan yang bisa terurai secara alamiah/biologis, seperti sisa makanan dan guguran daun. Sampah jenis ini juga biasa disebut sampah basah.

2. Sampah anorganik: sampah yang terdiri dari bahan-bahan yang sulit terurai secara biologis. Proses penghancurannya membutuhkan penanganan lebih lanjut di tempat khusus, misalnya plastik, kaleng dan styrofoam. Sampah jenis ini juga biasa disebut sampah kering.

3. Sampah bahan berbahaya dan beracun (B3): limbah dari bahanbahan berbahaya dan beracun seperti limbah rumah sakit, limbah pabrik dan lain-lain.

Kesadaran masyarakat untuk membuang sampah pada tempat-tempat tertentu masih rendah, apalagi untuk mengolahnya. Di setiap rumah tangga menghasilkan limbah kira-kira sebanyak $0,8 \mathrm{~kg} /$ hari atau $288 \mathrm{~kg}$ per tahun.

\section{PENDIDIKAN LINGKUNGAN}

Besarnya penduduk dan keragaman aktivitas di kota-kota metropolitan di Indonesia seperti Jakarta, mengakibatkan munculnya persoalan dalam pelayanan prasarana perkotaan, 
seperti masalah lingkungan. Kurangnya pemahaman karakter peduli lingkungan membuat manusia memenuhi kebutuhan dengan menjadikan alam sekitar sebagai alat pemuas. Alam sekitar sebagai tempat berlangsungnya kehidupan, sebenarnya membutuhkan peran manusia untuk tumbuh secara berkelanjutan. Alam dan lingkungan pada akhirnya bermanfaat untuk kepentingan hidup manusia beserta generasinya. Berdasarkan UU No. 23 Tahun 1997, lingkungan hidup secara garis besar diartikan sebagai "kesatuan ruang dengan semua benda termasuk di dalamnya manusia yang melangsungkan perikehidupan serta kesejahteraan".

Setiap orang diharapkan agar peduli akan lingkungannya sebagai tempat tinggal. Kenyataannya masih banyak masyarakat yang kurang peduli terhadap lingkungan. Kepekaan masyarakat mengenai pentingnya pelestarian lingkungan hidup, perlu terus ditingkatkan. Cara peningkatan kepedulian terhadap lingkungan hidup, diantaranya melalui penyuluhan mengenai isu-isu yang menjadi perhatian dunia seperti global warming.

Salah satu faktor pendorong untuk terwujudnya revitalisasi peduli lingkungan adalah dengan memberikan pendidikan lingkungan sedini mungkin agar terbentuk karakter dari masingmasing individu. Penanaman karakter menjadi hal yang vital untuk mengubah perilaku dari apatis menjadi berpartisipasi penuh dalam menyelamatkan lingkungan. Karakter peduli lingkungan yang sudah tertanam akhirnya dapat mempengaruhi setiap individu untuk respect kepada masalah lingkungan yang menjadi tanggung jawab setiap manusia. Perubahan kesadaran yang terjadi pada masyarakat diharapakan dapat menjadi panutan, sekaligus dapat turun tangan secara langsung agar terwujudnya karakter peduli lingkungan.
Pemahamam karakter peduli lingkungan menjadi penting untuk disosialisasikan agar hasilnya dapat dimanfaatkan oleh semua pihak untuk berpartisipasi menjaga lingkungan. Urgensi pendidikan lingkungan untuk membentuk karakter peduli lingkungan sejatinya meningkatkan pengetahuan dan kesadaran, khususnya mahasiswa agar memiliki tanggung jawab bersama dalam melestarikan lingkungan. Peran mahasiswa serta masyarakat menjadi elemen penting sebagai aktor pengelola yang harus memiliki karakter peduli lingkungan. Pemanfaatan lingkungan tidak sekedar memakai, tetapi juga mengelola dan melakukan penjagaan yang berkesinambungan tanpa mengorbankan lingkungan itu sendiri. Dari aspek tingkat pendidikan, masyarakat terpelajar dan memiliki status sosial tinggi cenderung memiliki pemahaman dan kesadaran yang positif bagi pengembangan kegiatan partisipasi pengelolaan lingkungan (Lusi A, 2011).

\section{SIMPULAN}

Dengan mendidik anak dari usia dini dalam pendidikan lingkungan diharapkan dapat membentuk karakter peduli lingkungan sehingga nanti akan membentuk masyarakat yang cerdas akan pengelolaan lingkungan. Pengelolaan lingkungan yang melibatkan semua komponen masyarakat yang saling membantu dapat mensadarkan dan mengubah paradigma masyarakat untuk mengelola lingkungan sebaik mungkin, sehingga akaan tercipta lingkungan yang diharapkan oleh masyarakat. Dengan mengelola lingkungan yang baik maka lingkungan pun akan memberik timbal balik yang baik. Baik suasana alam yang natural maupun barang-barang yang dapat didaur ulang untuk dibuat kerajinan yang bernilai ekonomis. Dengan adanya penyuluhan Berbasis Masyarakat 
diharapkan dapat membentuk karakter peduli lingkungan. Lingkungan tidak hanya dinikmati namun juga dirawat sehingga tidak akan membawa dampak negatif pada manusia. Jika manusia bijak lingkungan dapat membantu untuk dapat dijadikan barang-barang yang di daur ulang dan bernilai ekonomi dan ekologi.

\section{REKOMENDASI}

Pihak terkait diharapkan untuk melakukan penyuluhan lingkungan berbasis masyarakat. Penyuluhan berbasis masyarakat diharapkan dapat membentuk karakter peduli lingkungan. Lingkungan tidak hanya dinikmati namun juga dirawat sehingga tidak akan membawa dampak negatif pada manusia. Jika manusia bijak lingkungan dapat membantu untuk dapat dijadikan barang-barang yang di daur ulang dan bernilai ekonomi dan ekologi.

\section{DAFTAR PUSTAKA}

Anggatravis. (2010). Permasalahan dan Solusi Pengelolaan Lingkungan Hidup. Artikel Online https://id.scribd.com/doc/41705770/ Permasalahan-Dan-SolusiPengelolaan-Lingkungan-Hidup

Daniel, Valerina. (2009). Easy Green Living. Bandung: Hikmah.

Kodoatie, Robert J. (2003). Manajemen dan Rekayasa Infrastruktur. Yogyakarta: Pustaka Pelajar.
Lailia Nur, Anita. (2014). Gerakan Masyarakat dalam Pelestarian Lingkungan Hidup (Studi Tentang Upaya Menciptakan Kampung Hijau di Kelurahan Gundih Surabaya). Jurnal Politik Muda, Vol. 3 No. 3, AgustusDesember 2014, h. 285-287.

Lusi A, Herlina. (2011). Partisipasi Masyarakat dalam Pengelolaan Lingkungan hidup sebagai Upaya Menciptakan Pemukiman yang Sehat dan Nyaman Huni (studi di kelurahan Notoprajan Ngampilan Yogyakarta). Jurnal Penelitian Bapedda Kota Yogyakarta. No.06 April 2011. ISSN. 1978 - 0052. h. 42-44.

Meerwan, Agus. (2016). 7 Permasalahan Lingkungan dan pengelolaan lingkungan hidup. Online. 12 Januri 2016. http://blog.umy.ac.id/ directions $/ \mathrm{p}=24$

Sunaryo, Busyori dkk. (1995). Dampak Program Pengelolaan Sampah Berbasis Masyarakat sebagai Salah satu Program Corporate Social Responsibility Badak LNG terhadap Pembentukan Budaya Hijau (Green Culture) pada Masyarakat Kota Bontang. Universitas diponegoro, Semarang.

Undang-undang Nomor 23 Tahun 1997 tentang Lingkungan Hidup. 